\title{
PENGARUH MOTIVASI, KOMUNIKASI DAN STRES KERJA TERHADAP KEPUASAN KERJA KARYAWAN
}

\author{
Made Pradnya Paramita Saputra ${ }^{1}$ \\ I Gusti Ayu Dewi Adnyani \\ ${ }^{1,2}$ Fakultas Ekonomi dan Bisnis Universitas Udayana (Unud), Bali, Indonesia \\ e-mail: prdnyaparamita@gmail.com
}

\begin{abstract}
ABSTRAK
Organisasi dituntut untuk menciptakan sumber daya manusia yang berkualitas dan unggul, sehingga performa yang baik dalam kerja akan tercapai dan selanjutnya dapat pula mencapai tingkat kepuasan kerja yang tinggi. Kepuasan kerja merupakan perasaan positif tentang pekerjaan yang timbul berdasarkan penilaian terhadap situa sikerja.Tujuan dari penelitian ini adalah untuk mengetahui pengaruh motivasi, komunikasi, dan streskerja terhadap kepuasan kerja. Penelitian ini dilakukan di PT. PPILN Wilayah Bali. Jumlah populasi penelitian ini 50 orang karyawan dengan metode sampling jenuh. Pada penelitian ini pengumpulan data dilakukan melalui penyebaran kuisioner dengan menggunakan metode pengukuran data skala Likert.Teknik analisis yang digunakan dalam penelitian ini adalah regresi linear berganda. Untuk meningkatkan kepuasan kerja hendaknya meningkatkan motivasi yang dirasakan karyawan, melakukan komunikasi yang efektif di dalam organisasi dan stres kerja karyawan harus dikelola agar dapat meningkatkan kepuasan kerja
\end{abstract}

Kata Kunci:motivasi, komunikasi, stres kerja, kepuasan kerja

\begin{abstract}
Organizations are required to create quality human resources and superior, so that good performance in the work will be achieved and then also can achieve high levels of job satisfaction. Job satisfaction is a positive feeling about work that arises based on an assessment of the work situation. Employee job satisfaction is one of many aspects that need to be considered in an effort to improve the human resource capabilities of an organization. The purpose of this study was to determine the effect of motivation, communication, and job stress on job satisfaction. This research was conducted at PT. PPILN Bali Area. The population of this study is 50 employees with saturated sampling method. In this study data collection is done through the distribution of questionnaires using Likert scale measurement method. Techniques of the analyzes used in this study are multiple linear regression. To improve job satisfaction should increase the motivation felt by employees, make effective communication within the organization and employee stress must be managed in order to improve job satisfaction

Keywords: motivation, communication, job stress, job satisfaction
\end{abstract}


Made Pradnya Paramita Saputra, Pengaruh Motivasi...

\section{PENDAHULUAN}

Organisasi dituntut untuk menciptakan sumber daya manusia yang berkualitas dan unggul, sehingga akan meningkatkan performa yang nantinya mencapai tingkat kepuasan kerja yang tinggi. Seseorang dengan tingkat kepuasan kerja yang tinggi, maka akan memiliki perasaan yang positif terhadap pekerjaannya. Seseorang dengan tingkat kepuasan kerja yang rendah memiliki perasaan negatif terhadap pekerjaannya. Kepuasan kerja merupakan sikap emosional yang dirasakan oleh seorang karyawan. Karyawan akan bekerja dengan baik apabila mereka merasa puas dengan apa yang mereka harapkan.Menurut Nasution (2009) kepuasan kerja merupakan situasi terpenuhinya kebutuhankebutuhan seperti kebutuhan terhadap pekerjaan, tingkat supervisi, hubungan antar karyawan, kesempatan untuk berkarier serta kenaikan pangkat dan upah yang sesuai.

Ketidakpuasan karyawan dalam perusahaan akan berdampak negatif terhadap perilaku karyawan dalam mencapai tujuan perusahaan. Perilaku karyawan yang malas akan menimbulkan masalah bagi perusahaan berupa tingkat absensi yang tinggi, keterlambatan kerja, dan pelanggaran disiplin lainnya yang dapat mempengaruhi kepuasan keja karyawan. Sebaliknya perilaku karyawan yang merasa puas akan lebih menguntungkan bagi perusahaan atau organisasi.

Permasalahan dalam pengelolaan manajemen SDM dapat terjadi di organisasi apa saja, baik itu perusahaan yang bergerak dalam bidang jasa maupun manufaktur. Berdasarkan hasil wawancara dengan beberapa karyawan, bahwa terdapat beberapa permasalahan mengenai kepuasan kerja yang dilihat dari kurang 
puasnya dengan jenis pekerjaan yang dilakukan dalam organisasi dan ditemukan permasalahan yang berhubungan dengan timbulnya ketidakpuasan kerja pada karyawan PT. PPILN wilayah Bali, dilihat dari perilaku karyawan yang malas dan kurang bersemangat dalam menjalankan pekerjaannya, perusahaan sudah mentoleransi keterlambatan 10 menit dari jam dimulainya kerja yaitu pukul 08.00 WITA, akan tetapi ada beberapa karyawan yangdatang sekitar pukul 08.30 WITA. Motivasi adalah kekuatan yang muncul dari dalam ataupun dari luar diri seseorang dan membangkitkan semangat serta ketekunan untuk mencapai sesuatu yang diinginkan Daft (2010:373). Antonio dan Sutanto (2013) menyatakan bahwa motivasi kerja dapat ditunjukan dengan perilaku pekerja. Perilaku pekerja yang menunjukkan semangat kerja dapat membuat karyawan bekerja secara maksimal. Karyawan yang bermotivasi tinggi akan merasa lebih bahagia dan lebih bersedia untuk bekerja bagi organisasi (Bemana et al., 2013).Menurut Arsyad (2011:323), suatu proses yang mendorong seseorang untuk melakukan suatu kegiatan disebut motivasi. Berdasarkan wawancara awal yang telah dilakukan, terdapat indikasi yang mnenyebabkan ketidakpuasan karyawan karena motivasi kerja yang rendah. Hal tersebut timbul karena kurangnya motivasi kerja yang berasal dari diri sendiri maupun rekan kerja, terjadinya kejenuhan kerja yang menyebabkan karyawan tidak mempunyai gairah dalam menjalankan pekerjaannya karena merasakan pekerjaan yang membosankan dan jenis pekerjaan yang sama, suasana kerja yang kurang nyaman sepertisuara bising yang disebabkan karena perusahaan bersebelahan dengan gudang perusahaan motor yang dapat mengganggu konsentrasi terhadap pekerjaandan kurangnya kegiatan rekreasi yang dilakukan 
oleh perusahaan yang dapat menyebabkan kurangnya motivasi karyawan dalam bekerja.

Komunikasi sebagai sarana dalam penyampaian maupun pembagian tugas dalam organisasi merupakan solusi terhadap menurunnya kepuasan kerja karena dengan komunikasi kita dapat mempelajari perilaku seseorang (Madlock, 2008). Brahmasari (2012) dalam penelitiannya menyatakan komunikasi sebagai suatu pertukaran informasi. Ali dan Haider (2012) interaksi yang baik antar anggota akan menghasilkan komunikasi efektif. Disamping indikasi rendahnya motivasi, juga terdapat permasalahan lain yaitu komunikasi yang kurang efektif. Didukung hasil wawancara dengan beberapa karyawan, menyatakan bahwa adanya komunikasi yang kurang efektif antar rekan kerja, jika salah satu karyawan melimpahkan pekerjaannya kepada rekan kerja lainnya dan hasilnya tidak sesuai dengan apa yang diharapkan atasan maka karyawan tersebut akan saling menyalahkan. Permasalahan tersebut akan mengakibatkan adanya konflik yang berkepanjangan antar sesama karyawan yang timbul akibat komunikasi yang tidak dapat berjalan dengan efektif.

Stres kerja dan kepuasan kerja adalah masalah organisasi yang mempengaruhi kinerja dan pertumbuhan suatu organisasi dalam lingkungan yang kompetitif (Hans et al., 2014). Stres kerja adalah suatu perasaan tertekan yang dialami karyawan dalam menghadapi pekerjaan. Stres kerja ini dapat menimbulkan perasaan tidak tenang, kecemasan, emosi yang tidak stabil, sulit tidur, merokok yang berlebihan, suka menyendiri, kurang rileks, gugup dan mengalami peningkatan tekanan darah (Mangkunegara, 2011:28). Menurut 
Khalidi dan Wazalify (2013)pemicu stres adalah ketidakjelasan dari apa yang menjadi tanggung jawab pekerjaan, kekurangan waktu dalam penyelesaian tugas, kurangnya fasilitas yang mendukung untuk menjalankan pekerjaan dan tugas yang bertentangan. Berdasarkan hasil wawancara dengan beberapa karyawan, menyatakan bahwa terdapat masalah stres kerja yang dialami karyawan yaitu, adanya ketidakjelasan peran, dimana karyawan menjalankan pekerjaan yang tidak sesuai dengan bidangnya contohnya seperti karyawan bidang administrasi mengambil pekerjaan pada bagian bidang sertifikasi dan perivikasi begitupun sebaliknya dan kelelahan secara psikologis seperti karyawan sering menangis karena beban kerja yang berlebihan. Beban kerja yang berlebihan tersebut akan menimbulkan stres di lingkungan kerja. Karyawan yang bekerja dalam suasana tertekan tidak akan bisa memberikan hasil kerja yang baik. Hal tersebut sesuai dengan penelitian yang dilakukan oleh Hauck et al. (2008) yang menyatakan bahwa stres dapat ditingkatkan dengan penumpukkan beban kerja yang nantinya akan mengakibatkan penurunan pada kinerja.

Tujuan penelitian ini untuk menganalisis pengaruh motivasi, komunikasi dan stres kerja pada kepuasan kerja karyawan. Harapannyahasil penelitian ini dapat memberikan kontribusi empiris mengenai hubungan antara variabel motivasi, komunikasi, stres kerja dan kepuasan kerja bagi penelitian-penelitian selanjutnya dimasa yang akan datang. Dengan penelitian ini diharapkan menjadi sebuah informasi bagi PT. PPILN Wilayah Bali tentang bagaimana cara meningkatkan kepuasan kerja karyawan di perusahaan tersebut. 
Risambessy (2012) menemukan bahwa motivasi mempunyai peran yang sangat penting untuk meningkatkan kerja karyawan melalui pemenuhan kebutuhan yang diberikan organisasi untuk karyawan. Umar (2009:265) stres mempunyai potensi untuk mengganggu kepuasan kerja karyawan, tergantung dari berapa besar tingkat stres.meningkatnya stres kerja karyawan sebagai akibat ketidakmampuannya menghadapi masalah-masalah pekerjaan berpengaruh terhadap menurunnya kepuasan kerja karyawan (Che han dan Ketut Netra, 2014). Kerangka konseptual yang diajukan sebagai dasar penentu hipotesis ditunjukan pada Gambar 1 sebagai berikut.

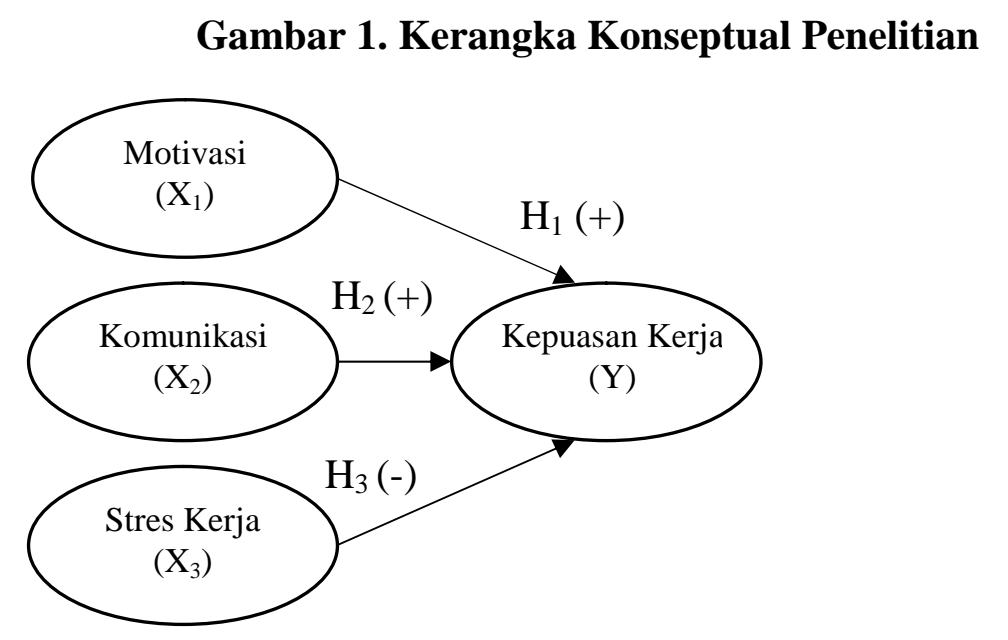

Kondisi suka atau tidak suka menurut pandangan seorang karyawan pada suatau pekerjaan adalah kepuasan kerja (Martin, 2008). Menurut Nasution (2009) kepuasan kerja merupakan situasi terpenuhinya kebutuhan-kebutuhan seperti kebutuhan terhadap pekerjaan, tingkat supervisi, hubungan antar karyawan, kesempatan untuk berkarier serta kenaikan pangkat dan upah yang sesuai. Randhawa (2007) mengatakan bahwa kepuasan kerja dapat diartikan dengan perasaan dan reaksi individu atau karyawan terhadap lingkungan 
pekerjaannyaatau dengan kata lain suatu ungkapan perasaan yang timbul dari hasil pengakuan terhadap pekerjaan (Turkyilmaz et al., 2011). Menurut Priansa (2016:301), faktor yang dapat mempengaruhi kepuasan kerja yaitu faktor fisik, faktor psikologi, faktor sosial dan faktor finansial. Faktor psikologi meliputi dan berhubungan dengan kejiwaan karyawan. Faktor sosial adalah faktor yang berhubungan dengan interaksi sosial karyawan, baik itu hubungan dengan atasan ataupun dengan rekan kerja. Faktor fisik berhubungan dengan kondisi fisik karyawan dan kondisi fisik lingkungan pekerjaan karyawan. Faktor finansial adalah faktor yang berhubungan dengan kesejahteraan karyawan.

Salleh et al. (2012) mengemukakan penilaian atau sikap seorang individu atas suatu pekerjaan sangat berhubungan dengan lingkungan, kompensasi dan sebagainya. Saleem et al. (2010) dalam penelitiannya menyatakan motivasi berpengaruh pisitif terhadap kepuasan kerja. Secara keseluruhan para karyawan puas dengan pekerjaan mereka dan memiliki ketertarikan terhadap pekerjaan mereka. Lebih dari rata-rata karyawan termotivasi untuk bekerja dalam organisasi. Shah et al. (2012) mengatakan bahwa bahwa motivasi berpengaruh positif secara signifikan terhadap kepuasan kerja karyawan. Berdasarkan penjelasan diatas, maka dapat disimpulkan hipotesis sebagai berikut.

$\mathrm{H}_{1}$ :Motivasi berpengaruh positif dan signifikan terhadap Kepuasan Kerja

Komunikasi adalah suatu proses percakapan dan penyampaian informasi dari seseorang, kelompok atau organisasi dengan maksud dapat dipahami (Setiawan, 2007). Karademir et al. (2014) menyatakan bahwa melalui komunikasi, para pekerja di organisasi dapat mengetahui apa yang diharapkan dari 
mereka dan apa yang dipikirkan manajemen dan rekan mereka tentang mereka. Selain itu, menyampaikan dan menerima pengetahuan memiliki peran dalam kehidupan organisasi, dan proses komunikasi yang efektif berperan dalam memungkinkan pekerja mengembangkan sikap positif.

Indikator komunikasi menurut Mangkunegara (2004:148) yakni pemahaman, kemampuan memahami pesan secara cermat sebagaimana dimaksudkan oleh komunikator. Dengan pemahaman yang cermat dari karyawan, pemimpin akan mudah menjelaskan mengenai tujuan perusahaan dan aturan yang ada di perusahaan. Suasana menyenangkan di dalam aktivitas kerja otomatis menimbulkan keharmonisan antar anggota perusahaan. Keharmonisan yang terjadi dalam perusahaan secara tidak langsung mendorong anggota perusahaan memiliki rasa kenyamanan untuk bekerja.

Pemimpin yang dapat mengkomunikasikan perintah atau aturan dengan baik otomatis dapat diterima dengan baik juga oleh karyawan yang secara tidak langsung dapat meningkatkan kepuasan kerja karyawan.Hubunganinterpersonal yang berlangsung dengan baik dapat meningkatkan semangat kerja yang secara tidak langsung dapat meningkatkan kepuasan kerja karyawan.Penyampaian informasi yang baik akan berpengaruh pada bagaimana seseorang menerima informasi yang kemudian dapat diaplikasikan dalam bentuk tindakan. Pemimpin yang baik akan mengomunikasikan informasi sebaik mungkin berkaitan dengan aturan perusahaan yang otomatis akan meningkatkan kepuasan kerja karyawan.

Diatmika (2013) mengatakan komunikasi berpengaruhh positif dan signifikan terhadap kepuasan kerja karyawan. Czech (2013) menemukan bahwa 
komunikasi yang efektif berpengaruh sgnifikan terhadap kepuasan kerja karyawan. Berdasarkan penjelasan diatas, maka dapat disimpulkan hipotesis sebagai berikut.

$\mathrm{H}_{2}$ : Komunikasi berpengaruh positif dan signifikan terhadap Kepuasan Kerja

Menurut Siagian (2014:300) Stres merupakan kondisi ketegangan yang berpengaruh terhadap emosi, jalan pikiran dan kondisi fisik seseorang. Stres adalah reaksi negatif terhadap peristiwa yang tidak mampu diatasi oleh individu (Lee et al., 2014). Sedangkan menurut Mangkunegara (2011:28) stres kerja adalah suatu perasaan tertekan yang dialami karyawan dalam menghadapi pekerjaan.Rini (2010) menyatakan stres kerja dapat dikaitkan dengan kendala dan tuntutan.Finney (2013:3) menyatakan stres kerja adalah suatu reaksi dari stresor organisasi dalam lingkungan kerja yang dapat dikatakan sebuah ancaman yang dirasakan pada keamanan individu. Stress kerja ini dapat menimbulkan perasaan tidak senang, kecemasan emosi yang tidak stabil, sulit tidur, merokok yang berlebihan, suka menyendiri, kurang rileks, gugup dan mengalami peningkatan tekanan darah.

Stres kerja berhubungan negatif dengan kepuasan kerja karyawan. Kepuasan kerja yang lebih rendah akan mengalami lebih banyak stres dalam bentuk beban kerja, konflik peran dan lingkungan fisik dibandingkan dengan kepuasan kerja yang lebih tinggi (Mansoor et al., 2011).Tidak puas dari pekerjaan mereka menunjukkan sikap negatif terhadap pekerjaan dan akan merasa stres pada pekerjaan mereka. Stres fisik atau psikologis adalah keadaan tertekan yang 
dialami oleh individu menghadapi tuntutan yang luar biasa dan kendala dalam pekerjaan mereka (Hans et al., 2014).

Stres kerja berpengaruh negatif dan signifikan terhadap kepuasan kerja. Tekanan yang brasal dari ketidakselarasan seseorang dengan lingkungannya dapat menimbulkan stres. Stres dialami apabila kebutuhan dan kemampuan seseorang tidak selaras dengan sarana dan tuntutan (Susilawati, 2013).Berdasarkan penjelasan diatas, maka dapat disimpulkan hipotesis sebagai berikut.

$\mathrm{H}_{3}$ :Stres Kerja berpengaruh negatif dan signifikan terhadap Kepuasan Kerja

\section{METODE PENELITIAN}

Penelitian ini dilakukan pada PT. PPILN Wilayah Bali yang terletak di Jalan Hayam Wuruk No 72 Denpasar. Lokasi ini dipilih karena ditemukannya permasalahan mengenainya kurangnya kepuasan kerja pada PT. PPILN Wilayah Bali yang diduga dapat dipengaruhi motivasi, komunikasi dan stres kerja. Obyek penelitian adalah variabel atau hal yang menjadi titik perhatian dalam sebuah penelitian. Obyek penelitian ini adalah Motivasi, komunikasi, stres Kerja dan kepuasan kerja.Berdasarkan dengan permasalahan yang akan diteliti, maka penelitian ini menggunakan pendekatan kuantitatif yang bersifat asosiatif untuk meneliti data yang bersifat statistik serta menguji suatu hipotesis dengan kuisioner berbentuk penyataan sebagai instrument yang dipakai. Hal ini dikarenakan terdapat hubungan kausal (sebab-akibat) antara variabel bebas (Motivasi, Komunikasi dan Stres Kerja) dengan variabel terikat (Kepuasan Kerja).

Robbins and Judge (2010:113) mendefinisikan kepuasan kerja sebagai perasaan positif tentang pekerjaan sebagai hasil evaluasi karakter pekerjaan 
tersebut.Indikator kepuasan kerja menurut Hariandja (2002) sebagai berikut 1). Pekerjaan Itu Sendiri, tugas yang menyenangkan sesuai dengan keahlian yang dimiliki karyawan. Indikator variabel ini diukur dari tanggapan responden mengenai ditugaskan sesuai dengan keahlian; 2). Gaji, imbalan finansial yang diterima secara adil oleh karyawan atas pekerjaannya. Indikator variabel ini diukur dari tanggapan responden mengenai karyawan menerima gaji secara adil; 3). Rekan Kerja, hubungan rekan kerja yang saling mendukung dalam menyelesaikan pekerjaan.Indikator variabel ini diukur dari tanggapan responden mengenai hubungan dengan rekan kerja berjalan dengan baik; 4). Promosi, kesempatan untuk mengembangkan diri dan memperluas pengalaman kerja. Indikator variabel ini diukur dari tanggapan responden mengenai kesempatan untuk ke jenjang karir yang lebih tinggi; 5). Atasan, atasan selalu memberikan arahan dalam melaksanakan pekerjaan. Indikator variabel ini diukur dari tanggapan responden mengenai atasan yang selalu memberikan arahan.

Motivasi menurut Ardana dkk. (2012:193)adalah sebagai berikut. 1) Penempatan Kerja, penempatan kerja berhubungan dengan pemberian tugas dan pekerjaan kembali seorang karyawan kepada pekerjaan barunya seusai dengan kompetensi yang dimilikinya. Indikator variabel ini diukur dari tanggapan responden mengenai penempatan kerja yang tepat; 2). Kondisi Pekerjaan, kondisi pekerjaan yang menyenangkan berkaitan dengan segala yang terdapat dilingkungan kerja yang dapat mempengaruhi karyawan secara langsung maupun tidak langsung. Indikator variabel ini diukur dari tanggapan responden mengenai suasana kerja yang nyaman pada saat bekerja; 3). Fasilitas Rekreasi, fasilitas 
Made Pradnya Paramita Saputra, Pengaruh Motivasi...

rekreasi merupakan aktivitas yang dilakukan semua karyawan diluar jam kerja yang diberikan untuk penyegaran misalnya liburan ke tempat rekreasi.Indikator variabel ini diukur dari tanggapan responden mengenai liburan ketempat rekreasi yang diberikan oleh kantor; 4). Promosi Jabatan, promosi jabatan berkaitan dengan diberikannya kesempatan mengembangkan diri bagi karyawan yang berprestasi dalam kantor.Indikator variabel ini diukur dari tanggapan responden mengenai diberikan kesempatan mengembangkan diri; 5). Jaminan kesehatan merupakan jaminan yang diberikan oleh perusahaan guna untuk meningkatkan rasa aman selama bekerja disuatu perusahaan.Indikator variabel ini diukur dari tanggapan responden mengenai karyawan diberi jaminan kesehatan oleh kantor.

Wahyudi (2013) menyatakan komunikasi sebagai sebuah proses penyampaian gagasan dan informasi dari seseorang kepada orang lain. Indikator yang digunakan pada variabel komunikasi (Mangkunegara, 2004:148) antara lain: 1). Pemahaman merupakan kemampuan memahami pesan secara cermat sebagaimana dimaksudkan oleh komunikator.Indikator variabel ini diukur dari tanggapan responden mengenaidapat memahami informasi yang disampaikan oleh rekan kerja; 2). Kesenangan apabila proses komunikasi itu selain berhasil menyampaikan informasi, juga dapat berlangsung dalam suasana yang menyenangkan ke dua belah pihak. Indikator variabel ini diukur dari tanggapan responden mengenaisenang ketika berkomunikasi dengan rekan kerja mengenai masalah pekerjaan; 3). Sikap akan dipengaruhi oleh komunikasi. Efektifnya komunikasi jika terjadi suatu perubahan setelah berkomunikasi. Indikator variabel ini diukur dari tanggapan responden mengenaiberkomunikasi dengan rekan kerja 
yang cenderung mengabaikan saran dan masukan orang lain; 4). Tingkat hubungan ahntar individu akan meningkat dengan baik setelah terjadi komunikasi yang efektif. Indikator Variabel ini diukur dari tanggapan responden mengenai rasa nyaman ketika berkomunikasi bertukar pikiran dengan atasan tentang masalah pekerjaan di kantor; 5). Tindakan, komunikasi akan efektif jika kedua belah pihak setelah berkomunikasi terdapat adanya sebuah tindakan. Indikator variabel ini diukur dari tanggapan responden mengenaiselalu memberikan yang terbaik untuk pelayanan di kantor.

Stres kerja merupakan suatu kondisi ketegangan yang menciptakan ketidakseimbangan antara fisik dan psikis, yang mempengaruhi emosi, proses berpikir, dan kondisi seorang karyawan (Sutrisno, 2010).Indikator stres kerja menurut Mulyadi (2003) yaitu: 1). Kondisi pekerjaan, suatu kondisi dimana karyawan merasakan beban kerja yang berlebihan. Indikator variabel ini diukur dari tanggapan responden mengenai beban kerja yang berlebihan; 2). Stres karena peran, suatu kondisi di mana para karyawan mengalami kesulitan di dalam memahami apa yang menjadi tugasnya. Indikator variabel ini diukur dari tanggapan responden mengenai ketidakjelasan peran; 3). Faktor interpersonal, faktor interpersonal merupakan hubungan kerjasama antar rekan kerja dan atasan.Indikator variabel ini diukur dari tanggapan responden mengenaihubungan kerjasama dengan atasan; 4). Perkembangan karir, perkembangan karir merupakan suatu proses dalam peningkatan dan penambahan kemampuan seseorang karyawan yang dilakukan secara formal dan berkelanjutan untuk mencapai sasaran dan tujuan karirnya.Indikator variabel ini diukur dari tanggapan 
Made Pradnya Paramita Saputra, Pengaruh Motivasi...

responden mengenai promosi jabatan yang lebih rendah dari kemampuan; 5). Struktur organisasi, struktur organisasi adalah bagaimana pekerjaan dibagi, dikelompokkan, dan dikoordinasikan secara formal. Indikator variabel ini diukur dari tanggapan responden mengenai struktur organisasi yang kaku.

Populasi dalam penelitian ini berjumlah 54 orang tidak termasukgeneral manager, manager verifikasi dan sertifikasi, manager administrasi dan keuangan, dan manager teknik dan operasi sehingga didapat jumlah populasi 50karyawan. Penelitian ini menggunakan sampel jenuh,yang dimana responden sebanyak 50 orang karyawan.

Tabel 1. Jumlah Populasi Penelitian

\begin{tabular}{llc}
\hline No & \multicolumn{1}{c}{ Bagian } & Populasi(orang) \\
\hline 1. & Supervisor Verifikasi dan Sertifikasi & 1 \\
2. & SupervisorAdministrasi dan Keuangan & 1 \\
3. & Supervisor Teknik dan Operasi & 1 \\
4. & Staf Verifikasi dan Sertifikasi & 6 \\
5. & Staf Administrasi dan Keuangan & 9 \\
6. & Pelaksana Pemeriksa & 32 \\
& Total & 50 \\
\hline
\end{tabular}

Sumber: PT. PPILN Wilayah Bali 2018

Wawancara adalah suatu cara pengumpulan data dengan melakukan tanya jawab secara langsung dengan beberapa karyawan yang berkaitan dengan Motivasi, Komunikasi, Stres Kerja dan Kepuasan Kerja.Kuisioner adalah teknik pengumpulan data yang dilakukan dengan menggunakan daftar kuisioner secara terstruktur yang disebarkan kepada seluruh responden dengan tujuan untuk memperoleh data mengenai bagaimana pengaruh motivasi, komunikasi dan Stres Kerja terhadap Kepuasan Kerja. Pengisian kuisioner menggunakan Skala likert. 
Kuesioner digunakan untuk memperoleh informasi dan data tentang variabel motivasi, komunikasi, stres kerja dan kepuasan kerja yang akan diuji pengaruhnya. Data variabel motivasi diukur dengan instrument motivasi yang dikembangkan oleh Ardana dkk. (2012). Pernyatan dalam sekala antara lain: Penempatan kerja yang tepat, suasana nyaman pada saat bekerja.

Data variabel komunikasi diukur dengan instrument Komunikasi yang dikembangkan oleh Mangkunegara (2004). Data variabel stres kerja diukur dengan instrument Stres Kerja yang dikembangkan oleh Mulyadi (2003). Data variabel kepuasan kerja diukur dengan instrument Kepuasan Kerja yang dikembangkan oleh Hariandja (2002). Pernyatan dalam sekala antara lain: karyawan menerima gaji secara adil, hubungan dengan rekan kerja berjalan dengan baik.

Penelitian ini menggunakan uji instrumen terlebih dahulu kemudian uji asumsi klasik.Analisis yang digunakan untuk menyelesaikan permasalahan dalam penelitian ini yaitu regresi linear berganda. Adapun persamaan regresi linear berganda rumusnya sebagai berikut:

$$
\mathrm{Y}=\alpha+\beta_{1} \mathrm{X}_{1}+\beta_{2} \mathrm{X}_{2}+\beta_{3} \mathrm{X}_{3}+\mathrm{e}
$$

Keterangan:

$\begin{array}{ll}\mathrm{Y} & =\text { Kepuasan kerja } \\ \alpha & =\text { Bilangan konstanta } \\ \mathrm{X}_{1} & =\text { Motivasi } \\ \mathrm{X}_{2} & =\text { Komunikasi } \\ \mathrm{X}_{3} & =\text { Stres Kerja } \\ \beta_{1} \beta_{2} \beta_{3} & =\text { Koefisien regresi variabel } \mathrm{X}_{1}, \mathrm{X}_{2}, \mathrm{X}_{3} \\ \mathrm{e} & =\text { Residual model }\end{array}$




\section{PEMBAHASAN}

Responden pada penelitian di PT. PPILN Wilayah Bali dominan berusia 21 sampai 30 tahun, dengan persentase sebesar 48 persen. Di lihat dari segi jenis kelamin, responden didominasi oleh jenis kelamin laki-laki dengan persentase 82 persen. Sebagian besar karyawan PT. PPILN Wilayah Bali mengenyam pendidikan terakhir Diploma yaitu sebanyak 25 orang dengan persentase 50 persen. Rata-rata persepsi responden mengenai motivasi secara keseluruhan sebesar 3,88 yang berarti motivasi yang dilakukan PT. PPILN wilayah Bali tergolong tinggi. Hasil tersebut berarti responden setuju bahwa kesesuaian pekerjaan dan timbal balik yang dirasakan memberikan tingkat motivasi yang tinggi.

Berdasarkan hasil deskripsi persepsi responden terdapat 1 indikator variabel dengan rata-rata skor terendah yaitu Penempatan kerja yang tepat memotivasi saya untuk menjalankan tugas dengan baik dengan skor 3,46. Sementara indikator motivasi yang memiliki skor diatas rata-rata adalah Kondisi pekerjaan yang nyaman memotivasi saya untuk bekerja dengan skor 4,00, Fasilitas rekreasi yang diberikan oleh perusahaan seperti liburan ketempat rekreasi memotivasi saya untuk bekerja dengan skor 3,94, Setiap karyawan diberi kesempatan mengembangkan diri atas prestasi kerja yang diperoleh dengan skor 3,88 dan Saya diberi jaminan kesehatan oleh kantor dengan skor 4,12.

Rata-rata persepsi responden mengenai variabel komunikasi secara keseluruhan adalah sebesar 3,68 yang berarti komunikasi yang dilakukan di PT. PPILN wilayah Bali tergolong tinggi. Hasil tersebut menggambarkan masing- 
masing responden merasa komunikasi yang dilakukan perusahaan berjalan dengan efektif. Berdasarkan hasil deskripsi persepsi responden terdapat 2 indikator variabel dengan rata-rata skor tertinggi yaitu saya merasa nyaman ketika berkomunikasi bertukar pikiran dengan atasan tentang masalah pekerjaan di kantor dengan skor 3,86, dan saya selalu memberikan yang terbaik untuk pelayanan di kantordengan skor 3,98. Sementara indikator komunikasi yang memiliki skor dibawah rata-rata adalah saya merasa takut bila berkomunikasi dengan rekan kerja yang cenderung mengabaikan saran dan masukan orang lain dengan skor 3,44, saya senang ketika berkomunikasi dengan rekan kerja mengenai masalah pekerjaan dengan skor 3,48, dan saya dapat memahami informasi yang disampaikan oleh rekan kerjadengan skor 3,64.

Rata-rata persepsi responden mengenai stres kerja secara keseluruhan sebesar 3,83 yang berarti stres kerja pada PT. PPILN wilayah Bali tergolong tinggi. Hasil tersebut berarti masing-masing responden setuju bahwa pekerjaan dan hubungan antar rekan kerjanya memberikan tingkat stres kerja yang tinggi. Berdasarkan hasil deskripsi persepsi responden terdapat 2 indikator variabel dengan rata-rata skor terendah yaitu saya memiliki hubungan kerjasama yang baik dengan atasan dengan skor 3,42 dan saya mendapatkan promosi jabatan yang lebih rendah dari kemampuan dengan skor 3,58. Sementara indikator stres kerja yang memiliki skor diatas rata-rata adalah saya merasa beban kerja yang diberikan berlebihan dengan skor 4,14, pekerjaan yang saya jalankan tidak jelas dengan skor 4,08, dansaya merasakan struktur organisasi yang kaku di dalam kantordengan skor 3,96. 
Made Pradnya Paramita Saputra, Pengaruh Motivasi...

Rata-rata persepsi responden mengenai variabel kepuasan kerja secara keseluruhan adalah sebesar 3,64 yang berarti kepuasan kerja pada PT. PPILN wilayah Bali tergolong tinggi. Hasil tersebut menggambarkan masing-masing responden merasa puas bekerja di perusahaan. Berdasarkan hasil deskripsi persepsi responden terdapat 2 indikator variabel dengan rata-rata skor tertinggi yaitu hubungan kerja saya dengan rekan kerja sudah berjalan dengan baik dengan skor 3,96 dankantor saya memberikan kesempatan untuk ke jenjang karir yang lebih tinggidengan skor 3,7. Sementara indikator kepuasan kerja yang memiliki skor dibawah rata-rata adalah saya ditugaskan sesuai dengan keahlian saya dengan skor 3,5, saya menerima gaji secara adil dengan skor 3,46 dan saya puas dengan arahan yang diberikan atasan dengan skor 3,58.

Pertama dilakukan uji instrumen yakni uji validitas bertujuan untuk menilai instrumen yang digunakan telah tepat untuk mengukur indikator dalam penelitian. Hasil pengukuran validitas masing - masing instrumen pada variabel disajikan dalam Tabel 2 sebagai berikut.

Hasil uji validitas instrumen penelitian disajikan pada Tabel 2 yang menunjukkan bahwa seluruh indikator memiliki nilai Pearson Correlation yang lebih besar dari angka 0,30 sehingga seluruh indikator tersebut dikatakan telah memenuhi syarat validitas data.

Hasil pengukuran reliabilitas masing-masing variabel disajikan dalam Tabel 3. 
Tabel 2.

Hasil Uji Validitas

\begin{tabular}{cccc}
\hline Variabel & Instrumen & Pearson Correlation & Keterangan \\
\hline & X1.1 & 0,646 & Valid \\
Motivasi & X1.2 & 0,529 & Valid \\
(X1) & X1.3 & 0,334 & Valid \\
& X1.4 & 0,399 & Valid \\
& X1.5 & 0,387 & Valid \\
X2.1 & 0,554 & Valid \\
Komunikasi & X2.2 & 0,386 & Valid \\
(X2) & X2.3 & 0,627 & Valid \\
& X2.4 & 0,417 & Valid \\
X2.5 & 0,369 & Valid \\
Stres Kerja & X3.1 & 0,314 & Valid \\
(X3) & X3.2 & 0,413 & Valid \\
& X3.3 & 0,524 & Valid \\
& X3.4 & 0,546 & Valid \\
& X3.5 & 0,363 & Valid \\
Kepuasan Kerja & Y.1 & 0,478 & Valid \\
(Y) & Y.2 & 0,510 & Valid \\
& Y.3 & 0,326 & Valid \\
& Y.4 & 0,350 & Valid \\
& Y.5 & 0,530 & Valid \\
\hline
\end{tabular}

Sumber:Data diolah, 2018

Tabel 3.

Hasil Uji Reabilitas

\begin{tabular}{ccc}
\hline Variabel & Cronbadh'sAlpha & Keterangan \\
\hline Motivasi & 0,784 & Reliabel \\
Komunikasi & 0,712 & Reliabel \\
Stres Kerja & 0,729 & Reliabel \\
Kepuasan Kerja & 0,803 & Reliabel \\
\hline
\end{tabular}

Sumber: Data diolah, 2018

Hasil uji reliabilitas instrumen pada penelitian ini disajikan pada Tabel 3 yang menunjukkan bahwa keempat instrumen penelitian memiliki koefisien cronbach's alpha yang lebih besar dari angka 0,60 sehingga pernyataan pada kuesioner dapat dikatakan reliabel dan indikator yang digunakan merupakan indikator yang konsisten.

Selanjutnya dilakukan uji asumsi klasik. Berdasarkan hasil analisis, diperoleh hasil sebesar 0,544 > 0,05 yang artinya data berdistribusi normal. 
Made Pradnya Paramita Saputra, Pengaruh Motivasi...

Kemudian koefisien Tolerance semua variabel lebih besar dari 0,10 dan nilai VIF yang lebih kecil dari 10. Hasil ini mengindikasikan bahwa tidak terdapat gejala multikolinear dari model regresi yang dibuat sehingga pada model regresi ditemukan korelasi antar variabel bebas.Hasil uji menunjukkan nilai signifikansi lebih dari 0,05 yang artinya model regresi bebas dari gejala heteroskedastisitas.Adapun hasil analisis linear berganda dapat dilihat pada tabel berikut:

Tabel 4.

Hasil Uji Analisis Regresi Linier Berganda

\begin{tabular}{|c|c|c|c|c|c|}
\hline \multirow[t]{2}{*}{ Model } & \multicolumn{2}{|c|}{ Unstandardized Coefficients } & \multirow{2}{*}{$\begin{array}{c}\begin{array}{c}\text { Standardized } \\
\text { Coefficients }\end{array} \\
\text { Beta }\end{array}$} & \multirow[t]{2}{*}{$\mathbf{t}$} & \multirow[t]{2}{*}{ Sig } \\
\hline & B & Std. Error & & & \\
\hline (Constant) & 10,655 & 5,111 & & 2,085 & 0,043 \\
\hline Motivasi & 0,455 & 0,122 & 0,469 & 3,726 & 0,008 \\
\hline Komunikasi & 0,239 & 0,144 & 0,188 & 2,655 & 0,014 \\
\hline Stres Kerja & $-0,164$ & 0,125 & $-0,130$ & & \\
\hline $\mathrm{R}$ & 0,682 & & & & \\
\hline $\mathrm{R}^{2}$ & 0,544 & & & & \\
\hline Adjusted $\mathrm{R}^{2}$ & 0,438 & & & & \\
\hline
\end{tabular}

Sumber: Data diolah, 2018

Berdasarkan Tabel 4. yang menyajikan hasil dari analisis regresi berganda, maka persamaan regresi yang digunakan dalam penelitian ini dapat ditulis sebagai berikut:

$\mathrm{Y}=10,665+0,455 \mathrm{X}_{1}+0,239 \mathrm{X}_{2}-0,164 \mathrm{X}_{3}+\mathrm{e}$

Koefisien determinasi total sebesar 0,438 , yang artinya sebesar 43,8 persen variasi kepuasan kerja dipengaruhi oleh motivasi, komunikasi, dan stres kerja, sedangkan sisanya sebesar 56,2 persen dipengaruhi oleh faktor-faktor lain yang 
tidak dimasukkan ke dalam model penelitian.Berdasarkan hasil uji, nilai signifikansi $\mathrm{F}$ adalah sebesar 0,004 yang lebih kecil dari $0,05(\mathrm{~F}<\alpha)$ yang berarti variabel bebasyaitu motivasi $\left(\mathrm{X}_{1}\right)$, komunikasi $\left(\mathrm{X}_{2}\right)$, dan stres kerja $\left(\mathrm{X}_{3}\right)$ berpengaruh signifikan secara serempak atau bersama-sama terhadap variabel terikat yaitu kepuasan kerja (Y), sehingga penelitian ini dapat dikatakan memenuhi uji kelayakan model atau model penelitian dinyatakan layak digunakan sebagai model regresi.

Hasil yang didapatkan dalam analis data dapat diketahui bahwa nilai sig. $\mathrm{t}$ sebesar 0,008 dengan nilai koefisien beta sebesar 0,455 Nilai sig. t yang menunjukkan nilai $0,008<0,05$ yang artinya $\mathrm{H}_{1}$ diterima. Motivasi berpengaruh positif dan signifikan terhadap kepuasan kerjakaryawan PT. PPILN Wilayah Bali. Artinya bahwa semakin tinggi motivasi yang dirasakan karyawan maka akanmeningkatkan kepuasan kerja karyawan.

Hasil penelitian ini sesuai dengan penelitian Apsari dan Riana (2017) menyatakan bahwa motivasi kerja berpengaruh positif dan signifikan terhadap kepuasan kerja. Hasil ini memiliki arti semakin tinggi motivasi yang dimiliki maka semakin tinggi pula tingkat kepuasan kerja karyawan. Khalid et al. (2011) menunjukkan bahwa motivasi berpengaruh positif secara signifikan terhadap kepuasan kerja karyawan. Saleem et al. (2010) menyatakan ada hubungan positif antara motivasi dan kepuasan kerja. Secara keseluruhan para karyawan puas dengan pekerjaan mereka dan memiliki ketertarikan terhadap pekerjaan mereka. Lebih dari rata-rata karyawan termotivasi untuk bekerja dalam organisasi. Shah et 
Made Pradnya Paramita Saputra, Pengaruh Motivasi...

al. (2012) menyatakan bahwa bahwa motivasi berpengaruh positif secara signifikan terhadap kepuasan kerja karyawan.

Berdasarkan hasil yang didapatkan dalam analis data dapat diketahui bahwa nilai sig. $\mathrm{t}$ sebesar 0,014 dengan nilai koefisien beta sebesar 0,239 . Nilai sig. $\mathrm{t}$ yang menunjukkan nilai $0,014<0,05$ yang artinya $\mathrm{H}_{2}$ diterima. Komunikasi berpengaruh positif dan signifikan terhadap kepuasan kerjakaryawan PT. PPILN Wilayah Bali. Artinya semakin efektif komunikasi yang dilakukan karyawan maka akanmeningkatkan kepuasan kerjakaryawan.Suastika dan Putra (2013) mengatakan komunikasi berpengaruh positif dan signifikan terhadap kepuasan kerja karyawan. Orebiyi (2011) menyatakan kepuasan kerja didapatkan dari komunikasi yang merupakan pertukaran informasi yang didalamnya terdapat dampak yang signifikan pada hasil pekerjaaan psikologis karyawan.Diatmika (2013) mengatakan komunikasi berpengaruh positif dan signifikan terhadap kepuasan kerja karyawan.Czech (2013) menemukan bahwa komunikasi yang efektif berpengaruh signifikan terhadap kepuasan kerja karyawan.

Berdasarkan hasil yang diperoleh dalam analis data dapat diketahui bahwa nilai sig. $\mathrm{t}$ sebesar 0,031 dengan nilai koefisien beta sebesar $-0,164$. Nilai sig. $\mathrm{t}$ yang menunjukkan nilai $0,031<0,05$ yang artinya $\mathrm{H}_{3}$ diterima. Stres kerja berpengaruh negatif dan signifikan terhadap kepuasan kerjakaryawan PT. PPILN Wilayah Bali. Artinya semakin tinggi stres kerja yang dirasakan cenderung akan menurunkan tingkat kepuasan kerja karyawan.

Hasil penelitian ini mendukung penelitian Bashir dan Ismail (2010) dan Mansoor et al. (2011) yang menyatakan stres kerja berhubungan negatif dengan 
kepuasan kerja karyawan. Hans et al. (2014) mengatakan stres kerja berpengaruh negatif dan signifikan terhadap kepuasan kerja karyawan. Susilawati (2013) menyatakan stres kerja berpengaruh negatif dan signifikan terhadap kepuasan kerja. Tekanan yang berasal dari ketidakselarasan seseorang dengan lingkungannya dapat menimbulkan stres.

Hasil dari penelitian ini memiliki implikasi teoritis dan praktis, secara teoritis penelitian ini menunjukkan motivasi berpengaruh positif dan signifikan terhadap kepuasan kerja, komunikasi berpengaruh positif dan signifikan terhadap kepuasan kerja dan stres kerja berpengaruh negatif dan signifikan terhadap kepuasan kerja. Hasil penelitian ini memberikan dukungan empiris dan dapat memperkuat penelitian-penelitian sebelumnya. Secara praktis penelitian ini diharapkan untuk memberikan manfaat bagi pemimpin dan karyawan PT. PPILN Wilayah Bali yaitu perusahaan harus melakukan pendekatan dengan cara terus menerus memotivasi karyawan agar kepuasan kerja karyawan meningkat. Perusahaan juga harus meningkatkan komunikasi, dengan adanya komunikasi yang efektif penyampaian maupun pembagian tugas dalam perusahaan bisa meningkatkan kepuasan kerja karyawan.

Terdapat keterbatasan yang mempengaruhi kondisi dari penelitian yang dilakukan yakni jumlah responden hanya dari lingkungan PT. PPILN Wilayah Bali, sehingga hasil penelitian ini hanya dapat diterapkan dilingkungan kerja PT. PPILN Wilayah Bali dan tidak dapat digeneralisir pada lingkungan perusahaan lain. Kemudian penelitian ini tidak mencantumkan faktor lain kedalam model dari sisa determinasi total sebesar 56,2persen yang dapat dijelaskan oleh faktor lain, 
Made Pradnya Paramita Saputra, Pengaruh Motivasi...

seperti komitmen organisasional, kepemimpinan, budaya organisasi, prestasi kerja dan organizational citizenship behavior $(O C B)$ terhadap variabel kepuasan kerja.

\section{SIMPULAN DAN SARAN}

Berdasarkan hasil analisis data serta pembahasan mengenai pengaruh masing-masing variabel yang telah dipaparkan, maka dapat ditarik kesimpulan sebagai berikut: 1). Motivasi berpengaruh positif dan signifikan terhadap kepuasan kerjakaryawan di PT. PPILN Wilayah Bali; 2). Komunikasi berpengaruh positif dan signifikan terhadap kepuasan kerjakaryawan di PT. PPILN Wilayah Bali; 3). Stres kerja berpengaruh negatif dan signifikan terhadapkepuasan kerja karyawan di PT. PPILN Wilayah Bali.

Saran yang dapat diberikan berkaitan dengan penelitian ini sebagai bahan pertimbangan serta masukan yang berguna bagi manajemen PT. PPILN Wilayah Balidimasa yang akan datang adalah perusahaan harus meningkatkan motivasi dalam hal penempatan kerja yang tepat bagi karyawan. Dengan penempatan karyawan yang tepat, akan meningkatkan semangat kerja dan karyawan bisa termotivasi untuk menjalankan tugas dengan baik.Dalam meningkatkan komunikasi dalam perusahaan, karyawan harus lebih berani untuk berkomunikasi dengan karyawan lainnya. Dengan demikian, komunikasi yang dilakukan dalam perusahaan akan berjalan efektif.

Untuk meminimalkan stres kerja karyawan, sebaiknya karyawan lebih menjalin hubungan kerjasama yang baik dengan atasan. Dengan demikian, tugas yang dikerjakan lebih cepat dan mudah diselesaikan. Meningkatkan kepuasan kerja karyawan, PT. PPILN Wilayah Bali harus memperhatikan pembagian gaji 
secara adil sesuai dengan keahlian dan tuntutan pekerjaan. Dengan demikian, kepuasan kerja karyawan akan meningkat.Bagi peneliti selanjutnya, diharapkan untuk melakukan penelitian dengan cakupan lain ataupun yang lebih luas yaitu seperti mencari lokasi penelitian selain PT, menggunakan sampel penelitian yang lebih banyak, menambahkan variabel-variabel lainseperti komitmen organisasional, kepemimpinan, budaya organisasi, dan organizational citizenship behavior $(O C B)$.

\section{REFERENSI}

Ali, Akbar dan Jahanzaib Haider. (2012). Impact of Internal Organizational Communications on Employee Job Satisfaction in Pakistani Banks. Journal of Business and Management Studies, 1 (X): 038-044.

Antonio, N. E dan Sutanto, E. M. (2013). Pengaruh Motivasi Dan Kepuasan Kerja Karyawan Terhadap Organizational Citizenship Behavior di CV Supratex. Jurnal Manajemen Bisnis. 2 (1): 656-664.

Apsari, Ni Made Mery dan I Gede Riana. (2017). Pengaruh Insentif Finansial, Insentif Non Finansial dan Motivasi Kerja terhadap Kepuasan Kerja. EJurnal Manajemen Unud. 6(3): 1592-1616

Ardana I Komang, Ni Wayan Mujiati, dan I Wayan Mudiartha Utama. (2012). Manajemen Sumber Daya Manusia. Cetakan Pertama. Yogyakarta: Graha ilmu.

Arsyad, Azhar. (2011). Media Pembelajaran, Jakarta: PT Raja Grafindo Persada.

Bashir, Usman and Muhammad Ismail Ramay. (2010). Impact of Stres on Employees Job Performance (A Study on Banking Sector of Pakistan). International Journal of Marketing Studies. 2(1): 122-126.

Brahmasari, Ida Ayu dan Paniel Siregar. (2012). Pengaruh Budaya Organisasi, Kepemimpinan Situasional dan Pola Komunikasi terhadap Disiplin Kerja dan Kinerja Karyawan pada PT Central Proteinaprima Tbk. Jurnal Aplikasi Manajemen, 7(1): 238-249.

Bemana, Simin, Hamideh Moradi., Mohsen Ghasemi.,Sayed Mehdi Taghavi and Amir Hosain Ghayoor. (2013). The Relationship among Job Stres and Job 
Satisfaction in Municipality Personnel in Iran. World Applied Sciences Journal, 22 (2): 233-238.

Czech, Kathleen dan G. L. Forward. (2013). Leadership, Communication, and Job Satisfaction: Perspectives on Subordinate Relationships to Supervisor. Studies in Media and Communication, 1 (2): 11-24.

Daft, Richard L. (2010). Era Baru Manajemen. Jakarta: Penerbit Salemba Empat

Diatmika, Paripurna. (2013).Pengaruh Lingkungan Kerja, Komunikasi Terhadap Kepuasan Kerjaa Karyawan.E-Journal Universitas Udayana, 2(5): 581-593.

Finney, Caitlin,Erene Stergiopoulos,Jennifer Hensel, Sarah Bonato and Carolyn S Dewa. (2013). Organizational Stresors Associated with A Job Stres and Burnout in Correctional Officers: a SystematicReview. BMC Public Health. 13(82) : 1-14.

Han, Che dan I Gusti Salit Ketut Netra .(2014). Pengaruh Konflik Terhadap Stres Kerja dan Kepuasan Kerja Karyawan. E-Jurnal Manajemen Universitas Udayana.3(8): 2150-2166

Hans, Arvind., Soofi Asra Mubeen., Sultan Khan., Abdulla Said Mohammed Al Saadi. (2014). A Study on Work Stres and Job Satisfaction among Headmasters: A Case Study of Bilingual Schools in Sultanate of Oman Muscat. Journal Of Sociological Research, 5 (1): 40-46.

Hauck, E. L\& Snyder, L.A. (2008). Workload and Variability and SocialSupport: Effect On Stress and Performance. Springer Science Business Media. 27 (2): $112-125$

Hariandja, Marihot T.E, (2002). Manajemen Sumber Daya Manusia. Jakarta: Grasindo.

Karademir, Tamer, Yunus Emre Karakaya, dan Yeliz Sirin. (2014). Physical Education Teachers' Preceptions of Organizational Culture and Communications in Educational Institutions. Journal of Physicial Education and Sport, 14(4): 637-642.

Khalid, Khalizani, Hanisah Mat Salim dan Siew-Phaik Loke. (2011). The Impact of Rewards and Motivation on Job Satisfaction in Water Utility Industry. International Conference on Financial Management and Economics. 11 (1): $35-41$

Khalidi, Doaa Al and Mayyada Wazaify. (2013). Assessmentof Pharmacusts JobSatisfaction and Job Related Stress in Amman.Jurnal Int J Clin Pharm, 35 (5): 821-828. 
Kiswanto, M. (2010). Pengaruh Kepemimpinan dan Komunikasi Terhadap Kinerja Karyawan Kaltim Pos Samarinda. Jurnal Eksis, 6 (1):126-143.

Lee, S., Yun, and Lee, S.Y. (2014). Moderating Role Of Social Support In The Stressor-Satisfaction Relationship. International Review Of Public Administration.20(1): 102-116.

Madlock, Paul E. (2008). The Link Between Leadership Style, Communicator Competence, and Employee Satisfaction. Journal of Business Communication, 45 (1): 61-78.

Mangkunegara, A.A. Anwar Prabu.(2004). Manajemen Sumber daya Manusia Perusahaan. Bandung: Rosda Karya. (2011). Manajemen Sumber Daya Manajemen Perusahaan. Bandung: Rosda Karya.

Martin, A and Roodt, G. (2008). Perceptions of organizational commitment, Job satisfaction and turnover Intentions in a post-Merger South African Tertiary Instituion. SA Journal Of Industrial Psychology, 33 (1): 23-31

Mansoor, Muhammad., Mohammad Ali Jinnah., Sabtain Fida., Saima Nasir and Zubair Ahmad. (2011). The Impact of Job Stres on Employee Job Satisfaction A Study on Telecommunication Sector of Pakistan. Journal of Business Studies Quarterly, 2 (3): 50-56

Nasution, Wendi Amsuri. (2009). Pengaruh Kepuasan Kerja Karyawan Terhadap Intensi Turnover Pada Call Center Telkomsel di Medan.Jurnal MANDIRI. 4(1): 3-5.

Orebiyi, A. O. (2011). The Influence of Interpersonal Communication on Secondary School Teachers' Job Satisfaction and Commitment in Kogi State, Nigeria. Journal of Communication and Culture: International Perspective, 2 (1): 109-117.

Donni Juni Priansa. (2016). Perencanaan dan Pengembangan SDM. Bandung: Alfabeta.

Randhawa, G. (2007). Relationship Between Job Satisfaction and Turnover Intentions: An Empirical Analysis. Indian Management Studies Journal, 11 (1): $149-159$

Rimsambessy, Agusthina Bambang Swasto, Armanu Thoyib, Endang Siti Astuti. (2012). The Influence of Transformational Ledership Style, Motivation, 
Made Pradnya Paramita Saputra, Pengaruh Motivasi...

Burnout towards Job Satisfaction and Employee Performance. Journal of Basic and Applied Scientific Research. 2(9): 8833-8842.

Rini. (2010). Pendekatan Yang Digunakan Dalam Mengatasi Stres Kerja pada Suatu Organisasi. Jurnal Ilmiah, 11 (3): 8-12.

Rivai, Veithzal dan Deddy Mulyadi. (2013). Manajemen Sumber Daya Manusia untuk Perusahaan, Dari Teori ke Praktik. Jakarta: PT Rajagrafindo Persada.

Robbins, S.P., and T.A., Judge, (2010), Organizational Behavior, Pearson Prentice Hall. United State of America: New York

Robbins, Stephen P. Dan Timothy A. Judge. (2008). Perilaku Organisasi Edisi Ke12, Jakarta: Salemba Empat.

Saleem Rizwan, Azeem Mahmood and Asif Mahmood, (2010). Effect of Wark Motivation on job Sotisfaction in Mobile Telecommunication Service Organizations of Pakistan. Internasional Journal of Busness and Management, 5 (11) : 213-222.

Salleh, R., Mishaliny, N.S., and Haryani, H. (2012). Job Satisfaction, organizational Commitment, and Turnover Intention: A Case Study on Employees of a Retail Company in Malaysia.World Academy Of Science, Engineering and Technology, 72 (1): 316-323

Shah, Muhammad Jamal, Musawwir-Ur-Rehman, Gulnaz Akhtar, Huma Zafar, Adnan Riaz. (2012). Job Satisfaction and Motivation of Teachers of Public Educational Institutions. International Journal of Business and Social Science. 3 (8) : 271-281

Setiawan, Mulyo Budi dan Bambang Sudarsono. (2007). Analisis Pengaruh Keefektifan Komunikasi, Kualitas Layanan dan Kepercayaan Terhadap Komitmen Keterhubungan (Studi PadaSTIE Stikubank Semarang). Jurnal Bisnis dan Ekonomi, 14(1): 66-89.

Siagian, Sondang P. (2014). Manajemen Sumber Daya Manusia. Jakarta: BumiAksara.

Suastika, Komang Ari dan Made Surya Putra. (2013). Pengaruh Kompensasi, Gaya Kepemimpinan Transformasional dan Komunikasi terhadap Kepuasan Kerja dan Semangat Kerja. E-Jurnal Universitas Udayana, 2(1): 17- 31.

Susilawati, Endang. (2013). Pengaruh Stres Kerja Terhadap Kepuasan Kerja Dan Kinerja Karyawan Pada PDAM Kabupaten Buton. Thesis Tidak Diterbitkan. Makasar: Jurusan Manajemen Fakultas Ekonomi dan Bisnis Universitas Hasanuddin 
E-Jurnal Manajemen, Vol. 8, No. 1, 2019: 6961 - 6989

Sutrisno, Edy. (2010). Manajemen Sumber Daya Manusia. Jakarta: Kencana. Prenada Media Group

Turkyilmaz, Ali, Akman Gulsen, Ozkan Coskun \& Pastuzak Zbigniew. (2011). Empirical Study of Public Sector Employee Loyalty and Satisfaction. Industrial Management \& Data Systems, Journal Management, 111(5): 675696.

Umar, Husein. (2007). Metode Penelitian Untuk Skripsi dan Tesis Bisnis. Jakarta: PT. Raja Grafindo Persada.

Wahyudi, I Wayan. (2013). Pengaruh Pelaksanaan Kepemimpinan, Komunikasi, dan Lingkungan Kerja Fisik Terhadap Kepuasan Kerja Karyawan Pada PT. Karang Bali Asli Tur Denpasar. E-Jurnal Manajemen Unud. 2(10): 12291242. 